\title{
X-ray test to evaluate the physiological potencial of Platypodium elegans Vog. Seeds (Fabaceae)
}

\author{
Kever Bruno Paradelo Gomes ${ }^{1}$ *; Juliana Martins Mesquita Matos²; Ildeu \\ Soares Martins'; Rosana de Carvalho Cristo Martins ${ }^{2}$
}

${ }^{I}$ Instituto Federal de Educação, Ciência e Tecnologia de Brasília-Campus Gama. Brasília-DF, Brasil.

2 Universidade de Brasília. Departamento de Engenharia Florestal.

Received March 11, 2016. Accepted Jun 30, 2016.

\begin{abstract}
The objective of this work was to evaluate the internal morphology of Platypodium elegans Vog. seeds through the X-ray tests and to verify their relation with germination. 200 radiographic images were taken of each group and the tests were taken with the seeds set at $28.0 \mathrm{~cm}$ from the source of x-rays. Next, the seeds were classified according to their internal morphology as seen in the radiographic images. Three categories of seeds were established: full, empty and partially full. For each seed category, germination tests were performed. Statistical design in factorial $3 \times 3$, with three groups and three categories. From the results obtained in this work, the use of x-ray test with Platypodium elegans Vog. seeds is promising in quality of seed groups detection, assisting in empty and partially full seeds separation, invalidating their immediate use or storage. The x-ray test, in $26 \mathrm{kV}$ for 1.2 seconds intensity was efficient in Platypodium elegans Vog. internal morpholy evaluation. There is a relationship between the internal morphology of seeds and the results of the germination test. The importance of a methodology of easy implementation, aiming at estimating the germinative power of the groups of seeds, was proved by the x-ray tests in seeds of Platypodium elegans Vog. and can also be used for the analysis of the internal morphology of other forest species.
\end{abstract}

Key words: Cerrado, image analysis, forest management, germination.

\section{Introduction}

Platypodium elegans Vog. popularly known as uruvalheira, jacarandá-docampo, faveiro, belongs to the Fabaceae family. It is a species which naturally occurs in the Cerrado and in the forestcerrado transition zone and is usually found in well-drained soils. It is widely used for commercial and ornamental purposes with its planting being more widely recommended in the agroforestry system in degraded areas recovery programs (Lorenzi, 2008; Pacheco et al., 2007; Lopes et al., 2010).

The morphophysiological quality evaluation of the seed groups is an essential process, which is of great importance for several phases of the production chain of the sector of seed production, significantly contributing for the maintenance and quality enhancement of this input. (de Melo et al., 2009; Albuquerque and Guimarães, 2008). The environmental compensations, like the compulsory replacement of native forests in rural properties, and the recovery of degraded areas, aiming at facing federal and state laws, prompted an increase in seed demands of native arbor forest species, which constitute basic input in the replacement and conservation programs of the ecosystem.

In this context, the use of non-destructive procedures which provide efficiency in the identification of empty, partially full and full seeds, like the x-ray testing may be considered an indicative of physiological quality of the seeds of these forestry species. 
The seed analysis through the radiographic images obtained through the x-ray testing is a relatively recent alternative in order to immediately classify the several internal morphological aspects of the seeds (Gomes, 2010). In this sense, the capture and processing of the image which has been $\mathrm{x}$-rayed has allowed the establishment of relations between integrity, morphology and determination of the physiological potential of the seeds (Marcos et al., 2010).

The forest species, particularly the ones from Cerrado, are characterized by the high incidence of predation, empty fruit and deficiency in the formation of the embryo. This way, the $\mathrm{x}$-ray test is recommended as it is a viable technique in the quality control of seeds (Gomes et al., 2014). Considering the economical interests and the conservation of the tree species of the Cerrado, it becomes necessary to intensify the research which is concerning the evaluation of the internal morphology of the seeds in order to help the identification of the seeds which hold potential on germination.

The germination test may become an obstacle for the evaluation of the physiological potential on forest seeds, considering the genetic elasticity that these species present and the long period demanded for the obtention of the results (Masetto et al., 2008).

Therefore, the objective of this paper was to evaluate the internal morphology of the seeds of the Platypodium elegans Vog. through the $\mathrm{x}$-ray tests and verify their relation to the germination process.

\section{Materials and methods}

The fruits of Platypodium elegans Vog. were collected in sensu stricto areas of the Federal District Region Cerrado at the point of physiological maturation directly on the tree, considering its vigor, stature and the sanity of the mother plants selected in September, 2014.

The choice of the region for the mother plants selection and formation of the seed groups was made considering the characteristic of the fragments of the vegetation found in urban centers (Group 1); Environmental protection area (EPA) addressed to the conservation and protec-tion of the ecosystem (Água Limpa Farm - University of Brasília) (Group 2) and along road BR 040 which connects Brasília (DF) and Cristalina (GO) in degraded environ-ments (Group 3). Fruits were harvested from 20 mother plants of each group.

The seeds were improved extracting the aliforms and submitted to the mechanical scarification, promoting a short cut on the side of the fruit, with the use of a pocket knife in the laboratory of seeds and forest nurseries belonging to the University of Brasília. The seeds were homogenized and stored in paper bags in B.O.D. type growth chamber under room temperature conditions of $25^{\circ} \mathrm{C}$ until the tests had been conducted in a period of 30 days. The samples for the tests were randomly extracted from each group of seeds. In each group, three samples of 20 seeds were extracted for the moisture content determination.

The samples were weighed with a digital precision scale of $0.001 \mathrm{~g}$ and after that procedure, the moisture content was analyzed with the standard greenhouse method at $105{ }^{\circ} \mathrm{C} \pm 3{ }^{\circ} \mathrm{C}$, for 24 hours (MAPA, 2009).

The x-ray test was conducted in the image analysis laboratory of the Department of vegetal production of the Superior School of Agriculture "Luiz de Queiroz", University of São Paulo (ESALQ/USP), in Piracicaba, SP. For the obtention of radiographic images of the seeds, we counted on the digital equipment Faxitron X-ray, model MX-20 DC-12, attached to a Core 2 Duo computer (3.16 GHz, 2 GB RAM memory, 160 GB Hard Disk) and MultiSync screen (LCD1990SX, of 17 inches). This way, 200 seeds of each group were $\mathrm{x}$-rayed and the images were obtained with the seeds placed at $28 \mathrm{~cm}$ far from the $\mathrm{x}$-ray emission source. The radiation intensity and the time of exposure of the seeds to the x-rays were automatically determi- 
ned by the $x$-ray machine. For the adequate positioning of the seeds during the exposition of the $\mathrm{x}$-rays, transparent doubleface sellotape was used on a rear projection transparency $(29.7 \times 21.0 \times 0.1 \mathrm{~cm})$.

After they were $\mathrm{x}$-rayed, the seeds were placed in individual cells of a plastic tray for later germination. The seeds were classified according to the internal morphology visualized in the radiographic images. Three categories of seeds were considered: empty, partially full and full.

The result of the X-rays was interpreted through the confront of the radiographic image and the respective image of the normal seedling, abnormal or dead or seed in state of dormancy after the germination test. For each category of seeds obtained through the X-ray test, the germination test was conducted in the Laboratory of seeds and forest nurseries belonging to the Forest Engineering Department of the University of Brasília, Brasília-DF.

The previously numbered seeds of Platypodium elegans Vog. were placed in filter paper roll (20 seeds/roll), stored in B.O.D. type growth chamber under $25^{\circ} \mathrm{C}$ and photoperiod of 8 hours/day. For soaking, distilled water was used in the proportion of 2.5 times its mass. The germination analysis was carried out in 30 days. The statistical delineation used was in a factorial scheme, with three groups and three categories $(3 \times 3)$, with the treatment replicated 20 times and the 10 experimental units placed totally at random. The analysis of variation (ANOVA) was carried out and the averages compared with the use of the Turkey's test, with probability at $5 \%$.

\section{Results and discussion}

The seeds of Platypodium elegans Vog. presented low level of moisture $(9-11 \%)$. The values which were obtained were similar to those presented by de Souza et al. (2008), when they found a $6-9 \%$ moisture level of the seeds of Platypodium elegans recently harvested in the region of Northern Cerrado of the state of Minas
Gerais. The low level of moisture found in the seeds of Platypodium elegans was fundamental to allow the adequate visualization of the internal parts of the seeds. Gomes et al. (2014), evaluating the internal morphology of the seeds of Terminalia argentea, verified that the low level of moisture in the seeds $(9-10 \%)$ led to a bigger optical density, which allowed a better visualization of the internal structures of the seeds which had been x-rayed.

The exposure of seeds of Platypodium elegans Vog. to the $\mathrm{x}$-rays, in radiation intensity of $26 \mathrm{kV}$ for 1,2 seconds, was efficient for the visualization of the internal morphology of the seeds. The images of the radiographed seeds allowed for an identification of the current internal state of the seeds, as well as the identification of seeds without embryonic tissues. In the same way, de Carvalho et al. (2009) verified that the potence of $25 \mathrm{kV}$, for 2 minutes, was enough to diagnose the internal structures of the seeds of Ocotea pulchella and of Persea pyrifolia, both belonging to the Lauraceae family.

In seeds of sucupira (Bowdichia virgilioides Kunth.) submitted to a radiographic analysis, the intensity of $30 \mathrm{kV}$ for 45 seconds was efficient to verify the internal parts of the seeds (Albuquerque and Guimarães 2008). The image analysis of the seeds of Platypodium elegans Vog., obtained through the tests of x-ray, was efficient for the evaluation of the internal condition of the sedes (Figure 1).

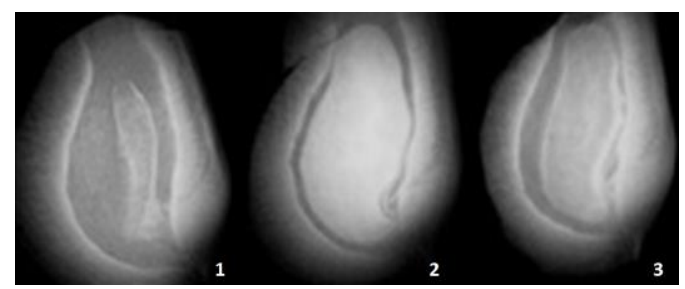

Figure 1. Seeds of Platypodium elegans Vog. classified as partially full (1), full (2) and empty (3) through the analysis of radiographic images.

Making use of the previous works on seeds of Tabebuia serratifolia debe-loped by de Oliveira et al. (2004) and through the 
indication of the rules for seed analysis (MAPA, 2009), it was possible to establish the criteria according to which we determined if the seeds could be considered full (totally formed), empty or partially full.

According to Table 1, it is possible to identify that groups 2 and 3 had a higher percentage of seeds that were perfectly morphologically formed (full) than group 1. This analysis was possible with the use of radiographic tests of $x$-ray.

The category full for all the groups was the one that presented the highest percentage of seeds of Platypodium elegans Vog., statistically differing from the categories empty and partially full. There was a significant statistic difference $(p<0.05)$ between the categories empty and partially full in all of the observations. The percentage of full seeds of the three groups varied between 65 and $80.5 \%$ (Table 1). These values were higher than the ones found by Sturião et al. (2012), when they evaluated the internal morphology of seeds of Syagrus romanzoffiana through the $\mathrm{x}$ ray tests; these authors found around $60.5 \%$ of viable seeds (full). According to MAPA (2009), fruit-seeds or seeds classified as full or totally formed by the $\mathrm{x}$ ray tests contain all the essential tissues for the germination and, because of this, they are considered viable.

The percentage between 15.5 and $25.5 \%$ (Table 1) of the seeds classified in the category empty is a sign that the process of classification of the seeds can be enhanced, avoiding unnecessary costs with the production of seedling and tests of laboratory. According to Gomes et al. (2014), the occurrence of empty seeds directly influences the storage, the efficiency of the sowing and the commercialization of groups of seeds. This fact is observed with some frequency in forest species where the structure of dispersion is not a true seed (de Souza et al., 2005)

Seeds that are partially full of Platypodium elegans Vog. were also found through the $\mathrm{x}$-ray tests, confirming the efficiency of this method in the detection of embryonic abnormalities. Even though they were the lowest values observed for all the groups $(4-10 \%)$ (Table 1), these seeds must be discarded before they are stored or sown, due to the high probability of producing abnormal seedling or non-germinating seeds and/or dead, inappropriate for the field development. In radiographed seeds of Cedrela fissilis Masetto et al. (2008) found around $30 \%$ of partially full seeds. According to the results of these authors, the deformation of the embryo precluded the normal development of the seedlings.

\section{Table 1}

Percentage of seeds of Platypodium elegans Vog. obtained in each category according to the $\mathrm{x}$-ray tests and the percentage of moisture

\begin{tabular}{ccccc}
\hline & \multirow{2}{*}{$\begin{array}{c}\text { Mois- } \\
\text { ture } \\
(\%)\end{array}$} & \multicolumn{3}{c}{ X-ray category $(\%)^{*}$} \\
\cline { 3 - 5 } & & Full & Empty & $\begin{array}{c}\text { Partially } \\
\text { Full }\end{array}$ \\
\hline 1 & 9.3 & $65.0 \mathrm{bA}$ & $30.0 \mathrm{~B}$ & $5.0 \mathrm{C}$ \\
2 & 10.4 & $85.0 \mathrm{aA}$ & $7.0 \mathrm{~B}$ & $8.0 \mathrm{C}$ \\
3 & 11.2 & $80.5 \mathrm{aA}$ & $15.5 \mathrm{~B}$ & $4.0 \mathrm{C}$ \\
\hline
\end{tabular}

* The averages that were followed by the same short letter in the horizontal line for the $\mathrm{x}$-ray categories and capital letters in the vertical line for the groups do not statistically differ among one another according to the Turkey's test at 5\% probability.

Forest arbor species like the Platypodium elegans Vog. which are recommended for the recovery of degraded areas, must hold groups of seeds with good genetic formation, as the seedlings that have been formed need good resistance and adaptability to poor soils; therefore, seeds that are partially full, damaged and/or empty, according to x-ray tests, must be eliminated from the programs of production of native seedlings. This aims at assuring good germination performance of the groups. The discard of seeds that are partially full, detected by the analysis of the radio-graphed seeds was also recommended by Machado and Cícero (2003) for seeds of Lithraea molleoides and by de Oliveira et al. (2003) for seeds of Peltophorum dubium, both resulted in the death of the seeds in the germination test. Therefore, as Amaral et al. (2011) have observed in seeds of Tabebuia 
heptaphylla, the radiographic images of the seeds of Platypodium elegans Vog. were fundamental to visua-lize the embryonic abnormalities, which were probably originated during the formation and maturation of the fruit.

When the results obtained in this work are taken into consideration, the use of x-ray tests in seeds of Platypodium elegans Vog. is promising in the quality detection of the groups of seeds, helping the separation of empty seeds and with embryonic abnormalities unfeasible for an immediate use or for storage.

For the percentage of germination, the analysis of the variation demonstrated significant effect among the categories obtained by the x-ray tests (Table 2), which resulted in no difference among the groups of seeds.

\section{Table 2}

Percentage of germination of three groups of seeds of the species Platypodium elegans Vog. found for the categories full, empty and partially full obtained through the analysis of the images of radiographic seeds

\begin{tabular}{clc}
\hline Group & X-ray categories & Germination $(\%)^{*}$ \\
\hline \multirow{2}{*}{1} & Full & $60.40 \mathrm{a}$ \\
& Empty & $0.00 \mathrm{~b}$ \\
& Partially full & $0.00 \mathrm{~b}$ \\
\hline \multirow{2}{*}{2} & Full & $70.23 \mathrm{a}$ \\
& Empty & $0.00 \mathrm{~b}$ \\
& Partially full & $0.00 \mathrm{~b}$ \\
\hline \multirow{2}{*}{3} & Full & $72.64 \mathrm{a}$ \\
& Empty & $0.00 \mathrm{~b}$ \\
& Partially full & $0.00 \mathrm{~b}$ \\
\hline
\end{tabular}

* The averages followed by the same letter do not statistically differ among one another according to the Turkey's test at 5\% probability.

For the three groups analyzed, the percentage of germination of the categories full statistically differed from the other categories. For the categories empty and partially full, $100 \%$ of non-germinating seeds were observed at the end of the germination test, which attests a correlation between the radiographic images by the $\mathrm{x}$-ray test and the results obtained through the germination test.

It is also important to mention that in the observation of the frequencies of seeds of the categories of $\mathrm{x}$-ray, the variation analysis allowed for the separation of the groups, however, when the results of the tests of germination were obtained, there was no significant effect among the groups, which did not prompt the choice of the group with highest vigor. This fact may be explained through the approximation of the values of percentage of germination of the categories full $(60.4-72.64 \%)$ and due to the fact that the categories empty and partially full do not obtain germinated seeds for all the groups. Pacheco et al. (2007) when evaluated pre-germination treatments in seeds of Platypodium elegans Vog., observed that the removal of part of the pericarp through the longitudinal cutting increased the permeability to water, which can, this way, induce a higher exposure to light and temperature, positively influencing the germination process of the seeds.

According to the results obtained in the germination test, the morphological perfect seeds (full) originated normal seedlings and non-germinated seeds. This kind of result is expected, as, in the radiography, the images indicate if there are or not formed tissues; however, they do not necessarily establish direct relation to the physiological processes of the seed. This analysis parameter was also observed by Pupim et al. (2008), in which some seeds with adequate characteristics, according to the $\mathrm{x}$-ray test, did not germinate, probably, due to the infection by microorganisms, mechanical damages and possible dormancy.

Along this work, it was possible to observe that the morphological conditions may influence the quality of the seeds. The $\mathrm{x}$ ray applied in this work revealed the unfeasibility of the seeds of Platypodium elegans Vog. which had imperfect or empty embryonic axes, as all the seeds of these categories (partially full and empty) did not germinate. This reality was also observed by Machado and Cícero (2003) in radiographed seeds of Lithraea molleoides submitted to the germination test. According to Carvalho and Oliveira (2006), the 
test of x-ray does not detect all the problems related to the physiological quality of the seeds, however, it enables a quick and non-destructive diagnosis for the examined seeds, providing useful and essential data for the research of laboratories of agriculture and forestry seed analysis as well as for the production of commercial seedlings.

In order to obtain a more detailed diagnosis, the technique of radiographic images analysis played an important role, as it was possible to visualize the current internal condition of the seeds and, as this technique is non-destructive, it was possible to establish cause and effect relations, after the test of germination had been checked (Figure 2).

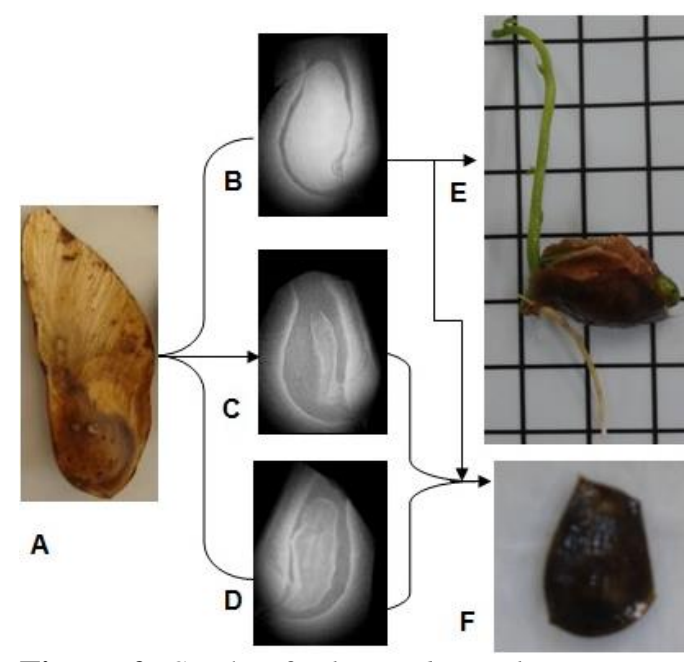

Figure 2. Seeds of Platypodium elegans Vog. visually intact (A), classified by the radiographic analysis as Full seeds (B), Partially full seeds (C) and Empty seeds (D); originating normal seedling (E) and non-germinated seeds and/or dead (F).

In the Figure $2 \mathrm{~B}$, it can be observed in the $\mathrm{X}$-ray images, full seeds, which contribute to a positive effect on the germination with the development of a normal seedling (Figure 2E). However, in the Figure 2C and $2 \mathrm{D}$, it is possible to observe empty and imperfect seeds that did not germinate (Figure 2F). Full seeds also resulted in non-germinated seeds after the germination test. Abnormal seedlings were not observed in any of the groups. These results were similar to the ones found by de Souza et al. (2008), in seeds of Platypodium elegans. For these authors, the obtained data attests that the assumption that the internal morphology of the seeds can be an indication of their viability. For Albuquerque and Guimarães (2008), the x-ray test in seeds of Bowdichia virgilioides, when related to the germination test, can help in the evaluation of the physical quality of the seeds.

The external simultaneous analysis of the seeds of the Platypodium elegans Vog., their respective radiographed images, normal seedlings and in state of dormancy or dead seeds deriving from the test of germination, permitted the diagnosis for each studied case. Hence, if the external image of the seeds were analyzed isolatedly, (Figure 2A), the imprecision of the diagnosis would be clear, as, this way, it would not be possible to identify internal damages or the frequency of seeds without embryonic tissues. According to de Carvalho and de Oliveira (2006), the test of x-ray does not detect all the problems related to the physiological quality of the seeds, howe-ver, it allows for a quick and non-des-tructive diagnosis for the examined seeds, providing useful and essential data for the research of laboratories of agriculture and forestry seed analysis as well as for the production of seedlings. The adequation of the $\mathrm{x}$-ray test applied to the native Forest seeds of the Cerrado, as the one considered for this study, provides agility in the identification of the viability and physio-logical quality of the groups of seeds to be used in the production of seedlings.

\section{Conclusions}

The x-ray test in radiation intensity of 26 $\mathrm{kV}$ for 1.2 seconds, is efficient in the evaluation of the internal morphology of the seeds of Platypodium elegans Vog. There was relation between the internal morphology of the seeds and the results of the germination test. The radiographic images showed that the detected damage 
affected the germination of the seeds of Platypodim elegans Vog.

The importance of a methodology of easy implementation, aiming at estimating the germinative power of the groups of seeds, was proved by the x-ray tests in seeds of Platypodium elegans Vog. and can also be used for the analysis of the internal morphology of other forest species.

\section{Acknowledgements}

Pro-rector of Research and Innovation of Instituto Federal of Brasília (PRPI-IFB) and University of Brasília for financial support.

\section{References}

Albuquerque, K.; Guimarães, R. 2008. Avaliação da qualidade de sementes de sucupira-preta (Bowdichia virgilioides Kunth.) pelo teste de raios $\mathrm{X}$. Revista Ciência e Agrotecnologia 32(6): 1713-1718.

MAPA - Ministério da Agricultura, Pecuária e Abastecimento. 2009. Regras para análise de sementes. SDA: Brasília: MAPA. 399 p.

de Carvalho, M.L.M; de Oliveira, L.M. 2006. Raios X na avaliação da qualidade de sementes. Informativo Abrates 6(1): 93-99.

de Carvalho, L.R.; de Carvalho, M.L.M.; Davide, A.C. 2009. Utilização do teste de raios $X$ na avaliação da qualidade de sementes de espécies florestais de Lauraceae. Revista Brasileira Sementes 31: 57-66

de Melo, P.; Oliveira, J.; de Carvalho, M.; Guimarães, R.; Carvalho, B. 2009. Aplicação do teste de raios x no estudo da morfologia interna e da qualidade fisiológica de aquênios de arnica (Lychnophora pinaster Mart.). Revista Brasileira de Sementes 31(2): 146-154.

de Oliveira, L.M.; de Carvalho, M.L.M.; Davide, A.C. 2003. Utilização do teste de raios-X na avaliação da qualidade de sementes de canafístula (Peltophorum dubium (Sprengel) Taubert. Revista Brasileira Sementes 25: 116-120.

de Oliveira, L.; de Carvalho, M.; Giimarães, R.; Masetto, T. 2004. Avaliação da qualidade de sementes de Tabebuia serratifolia Vahl Nichi. e T. impetigiosa (Martius ex A. P. de Candolle Standley) (Bignoniaceae) pelo teste de raios x. Revista Brasileira de Sementes 26(2): 138-143. de Souza, L.A.; dos Reis, D.N.; dos Santos, J.P.; Davide, A.C. 2008. Uso de raios x na avaliação da qualidade de sementes de Platypodium elegans Vog. Revista Ciência Agronômica 39(2): 343-347.

de Souza, L.A.; Mesquita, H.A.; Alvarenga, M.I.N.; Davide, A.C. 2005. Utilizacao de raios-X na avaliacao da qualidade fisiologica de sementes de sucupira branca (Pterodon emarginatus VOG). Informativo Abrates 15: 284-290.

do Amaral, J.; Martins, L.; Forti, V.; Cícero, S.; Marcos, F.J. 2011. Teste de raios x para avaliação do potencial fisiológico de sementes de ipê-roxo. Revista Brasileira de Sementes 33(4): 601-607.

Gomes, J.F.G. 2010. Aplicação da análise de imagens para avaliação da morfologia interna de sementes. Informativo Abrates 20(3): 33-51.

Gomes, K.; Martins, R.; Martins, I.; Gomes, J.F. 2014. Avaliação da morfologia interna de sementes de Terminalia argentea (Combretaceae) pelo teste de raios -X. Revista Ciência Agronômica 45(4): 752-759.

Lopes, S.; Oliveira, A.; Neves, S.; Shiavini, I. 2010. Dispersão de sementes de uruvalheira (Platypodium elegans Vog.) (Fabaceae) em um cerradão, Uberlândia - MG. Revista Arvore 34(5): 807-813.

Lorenzi, H. 2008. Árvores brasileiras: manual de identificação e cultivo de plantas arbóreas do Brasil. 1: 5 ed. Nova Odessa, SP. Instituto Plantarum.

Machado, C.; Cicero, S. 2003. Aroeira-branca (Lithraea molleoides (Vell.) Engl. - Anacardiaceae) seed quality evaluation by the X-ray test. Scientia Agricola 60(2): 393-397.

Marcos, F.J.; Gomes, J.F.; Bennett, M.; Wells, A.; Stieve, S. 2010. Using tomato analyzer software to determine embryo size in x-rayed seeds. Revista Brasileira de Sementes 32(2): 146-153.

Masetto, T.; Faria, J.; Queiroz, S. 2008. Avaliação da qualidade de sementes de cedro (Cedrella fissilis Meliaceae) pelo teste de raios X. Ciência e Agrotecnologia 32(6): 1-7.

Pacheco, M.; Matos, V.; Barbosa, M.; Ferreira, R.; Passos M. 2007. Germinação de sementes de Platypodium elegans Vog. submetidas a diferentes tratamentos prégerminativos e substratos. Revista Brasileira de Engenharia Agrícola e Ambiental 11(5) 497-501.

Pupim, T.; Novembre, A.; Carvalho, M.; Cicero, S. 2008. Adequação do teste de raios $\mathrm{x}$ para avaliação da qualidade de sementes de embaúba (Cecropia pachystachya Trec.). Revista Brasileira de Sementes 30(2): 28-32.

Sturião, W.; Landgraf, P.; Rosa, T. 2012. Avaliação da qualidade fisiológica de sementes de palmeira jerivá pelo teste de raios x. 2012. Semina: Ciências Agrárias 33(1): 213-218. 